\title{
THE COURT OF ROSTYSLAV MYKHAILOVYCH, PRINCE AND DOMINUS OF MACHOU, IN HUNGARY (AN EXCERPT FROM A FAMILY HISTORY BETWEEN THE LATE $13^{\mathrm{TH}}$ AND MID $14^{\mathrm{TH}}$ CENTURIES)
}

\author{
MYROSLAV VOLOSHCHUK
}

\begin{abstract}
One of the least-explored aspects of the biography of the Ruthenian Prince Rostyslav Mykhailovych, a maternal nephew of King Daniel Romanovych of Rus', is his court in a new homeland, the Kingdom of Hungary, between 1242/43 and 1262/64. It is known from various sources that he had numerous supporters among the secular and clerical nobility not only in Hungary but also in the lands of Galicia, Chernihiv, and Bolokhov. To date, however, too little information has been obtained from historical records containing clear mention of individuals who threw in their lot with the runaway prince in the lands of King Bela IV, especially after the defeat at Yaroslav on August 17, 1245. Having verified chronicles and Hungarian charters, the author concludes that the family of Rostyslav Mykhailovych and Princess Anna might well have been related to Lev and his sons, Fedir and Stephan, who were lords of Borod Land near Mukachevo in Bereg County. These people, who must have been descended from the nobility of Chernihiv or Galicia, succeeded one another in an effort to put Prince Rostyslav himself or his second cousin Iziaslav Volodymyrovych on the Galician throne throughout the 1240 s and 1250 s, all to no avail. What is important is that such attempts were always timed to coincide with the Mongol threat to the lands of the Romanids, which provided the claimants to the Galician throne with additional (albeit missed) chances of success. Their loyalty to the son-in-law of the Hungarian king was rewarded by the latter's daughter Anna (terminus ante quem 1264); she granted them lands, which were afterwards in the successive possession of the last members of the Arpad dynasty on the Hungarian throne as well as the new kings from the Anjou dynasty. Borod Land remained in the family's possession at least until the second half of the 14 th century.
\end{abstract}

Keywords: Rostyslav Mykhailovych, Princess Anna, Iziaslav Volodymyrovych, Halych, Galicia, noblemen Lev and his sons Fedir and Stephan, Bereg County, Mukachevo, Borod Land, Svaliava, the 13th-century Chronicle of the Romanids, Hungarian charters.

\section{INTRODUCTION}

The poetics The 2019 publication by Dr. Đura Hardi [1], a historian from Novi Sad, provides new insights into the biography of Rostyslav Mykhailovych († before July 16, 1264), one of the most extraordinary princes of the $13^{\text {th }}$ century, who, among other things, occupied the Galician throne. The Itinerarium of the Ruthenian prince reflects the dynamics of his life and reign; and in terms of geography, it is almost on a par with the itinerary of his famous maternal uncle King Daniel 
Romanovych of Rus' († 1264) [2, p. 7-34; 3, p. 207-227]. While this short but very compact and informative monograph of the Serbian scholar summarizes the biographical findings about the prince, it practically makes no mention of the long-standing historiographic issues associated with the prince's family ties [4, p. 52-57; 5, p. 453-475; 6, p. 465-466; 7; 8, p. 844; 9, p. 12-19; 10, p. 99-129], the lives of his relatives [11], as well as his court in Hungary composed of runaway boyars or Galician clergy ${ }^{*}$, among others. In his book, Đ. Hardi mentions these issues only in passing, thus pursuing a somewhat different research objective.

\section{ANALYSIS AND DiscUSSION}

Our interest in the above-mentioned issues, as exemplified by [15, p. 177-178, 268-269, 373; 16, p. 112-121], has led us to conduct this small study intended to expand our knowledge about the circle of Ruthenian boyars who were in close contact with Rostyslav Mykhailovych and his family through a comparative analysis of the well-known chronicles and Hungarian charters of the $13^{\text {th }}$ and $14^{\text {th }}$ centuries. Moreover, this research is motivated not only by the recent extensive archaeographical studies of the 13th-century Chronicle of the Romanids (commonly referred to as "The GalicianVolynian Chronicle") conducted by Polish and Slovakian researchers [17; 18] or the textual criticism of its particular parts performed by Ukrainian historians ${ }^{* *}$, but also by the continuous, meticulous work of Hungarian researchers with a view to publishing Hungarian medieval charters [20].

In the context of this research, it is important to consider several key events in Prince Rostyslav's life at the turn of the 1230s and 1240s which determined his destiny in the Hungarian Kingdom. Aided by his father Mykhailo Vsevolodovych ( +1246$)$, the prince, still rather young, took possession of Halych at the turn of 1235 and 1236; he enjoyed considerable support from the nobility, both local and newly arrived with the Olhovids from Chernihiv Land. However, during his campaign against the Lithuanians in 1238 (supposedly at the head of a Galician contingent in alliance with Prince Konrad of Masovia), he had to relinquish the city to his maternal uncle Daniel Romanovych and flee to Hungary. Throughout the year 1239, Mykhailo Vsevolodovych made numerous attempts to marry Rostyslav to any daughter of King Bela IV ( +1270$)$, all to no avail. The Mongol invasion of 1239-1241, the seizure of Chernihiv and Kyiv by the nomads, the plunder on the territory of the Romanids and the campaign against Hungary and Poland forced Prince Mykhailo's family to wander the Piast lands in Volyn', finally returning to Chernihiv Land in the summer of 1241. From there, Rostyslav Mykhailovych, helped by his various allies, made another attempt to reestablish himself in Halych, but all in vain. For some obscure reasons, without the mediation of Mykhailo Vsevolodovych, Bela IV did marry his daughter Anna ( + after 1270) to him at the turn of 1242 and 1243; and as his overlord (Galitiae Lodomeriaequae Rex), Bela IV guaranteed his son-in-law support in his further fight for the Galician throne. Yet, Rostyslav did not succeed; and after Hungarian and Polish allied forces were totally defeated by the Volynian princes Daniel and Vasylko, the Romanids, († 1270) at Yaroslav on August 17, 1245 , he fled to Hungary never trying to take possession of Halych again [1, p. 124-125]. His future was closely connected with the new fatherland. By the way, Rostyslav was the only Ruthenian prince to marry a daughter of a ruling Hungarian king and yet choose to join his father-in-law's court; he became Dominus of Machou, with June 28, 1254 regarded as the datum ante quem for the title being conferred upon him [21, p. 19-20; 1, p. 91].

Needless to say, the prince must have been surrounded by a certain hitherto little-known court or retinue recorded in an onomasticon, whose origin has always been somewhat unclear. The court of Rostyslav Mykhailovych, the number of his Ruthenian allies among the boyars might have continued to increase in subsequent years. We have previously presumed that the father of the would-be-lord

\footnotetext{
* For details about individual persons, see [12, p. 79-90; 13, p. 161-172]. The names of these individuals defy identification. In addition, it is commonly known that a Ruthenian contingent of considerable size allied itself with King Bela IV of Hungary and fought in the battle against Duke Frederick of Babenberg on June 15, 1246; according to the latest research findings, it was Prince Rostyslav with whom the duke was associated [14, p. 63; 1, p. 86-90].

${ }^{* *}$ Relevant in this regard is the paper by a Kyivan researcher [19, p. 447-462].
} 
Peter Petenye, also named Peter, might have belonged to the young prince's court [15, p. 373]. It is highly likely that Artemii, a former bishop of Halych [17, p. 205, 254, 257], as well as Bishop X of Peremyshl (his name being unknown) [17, p. 255], might have gone to Hungary to join Rostyslav. There were certain boyars from Chernihiv who received allotments of land from Dobroslav Suddych in Kolomyia Volost', with the terminus ante quem being 1241 [17, p. 243]. Nothing is known about the lives of those people after the arrest of the disgraced boyar by Prince Daniel in the second half of 1241 . Both they and the numerous Galician supporters of Rostyslav, whose names are frequently mentioned in the chronicle from the late 1230s to the early 1240s, could continue to serve their prince outside his former homeland. In order to do that, they had to move to Hungary and receive lands there, like many boyars of various origins had done before [15, p. 166-177, 182-184, 191-193, 195-198, 202-203]. Such a tradition is known to have continued. This might also have been connected with Prince Rostyslav's personal relations with his supporters among the nobility of Chernihiv or Halych.

Thus Mykhailo Hrushevskyi noted the diploma confirmed by Junior Queen Elisabeth ( $\dagger$ around 1290 ) in 1264; it mentions certain noblemen who served Anna, Prince Rostyslav's wife. The historian referred to them as "Ruthenians by origin or authochtons" [22, p. 501]. Let us consider the context and content of the document.

“Nos E(lisabeth) dei gracia iunior regina Hungarie, ducissa Transsilvana, domina Cumanorum, significamus universis quibus expedit per presentes, quod Lve cum duobus filii suis Fudur scilicet et Stephano, ad nostram accedens presentiam, nobis humiliter suplicavit petens, ut terram Borod vocatam [possibly present-day Barbovo Village in Mukachiv District, Transcarpathian Region, Ukraine. The possibility of interpreting the toponym as Brod, i.e. "ford", is not rejected either. $-M$. V.] in comitatu de Bereg sitam prope Munkaach [present-day Mukachevo in Mukachiv District, Transcarpathian Region, Ukraine. $-M . V$.] sibi per dominam Annam ducissam de Machov, sue de Bazna perpetualiter collatam, prout in literis eiusdem domine Anne exinde confectis nobis per predictum Lve presentatis vidimus contineri, eidem pacifice relinquentes, nostrarum eciam patrocinio literarum dignaremur confirmare" [23, p. 98].

Chronologically, the confirmantion of the land tenure coincided with Prince Rostyslav's death, which occurred between 1262 and 1264, with around December 17, 1263 being the datum ante quem, as per Đ. Hardi [1, p.120]. While it is difficult to identify the date of Anna's land tenure and state conclusively that the need for the confirmation arose from the Dominus of Machou's death, it seems possible that the group of boyars in question belonged to the court of Anna and her Ruthenian husband. What is particularly intriguing is the onomasticon of the newly arrived men, Lev and his two sons, Fedir and Stephan, especially in the context of examining the textual complexity of the chronicle, which has hitherto been dated 1255 and which we consider to be thematically connected with Princess Anna's diploma cited above:

“В та ж[е] лбта - или преже, или потом[ь] пріё хавше татаре къ Бакотъ, и приложисА Милей [first Prince Daniel's boyar, then the Tatars' accomplice. - M. V.] к ним[ъ]. І Данилови [Romanovych. - M. V.] ж[е] пошед[ъ]шю на воиноу на литвоу на Новъгородок[ъ], । быв[ъ]шю роскалю, посла с[ы]на си $\Lambda[$ ьв ва [Danylovych, + 1301. - M. V.] на Бакотоу. Пославь । Девъ двор[ь]ского пред[ъ] собою. Изьехав[ъ]ше, æша МилъА I и баскака, и приведе Левъ МилъА шт[ь]цоу си, и быс[ть] пакы | Бакота королева, w[ть]ца его. Потом[ь] же здоумавь сь с[ы]ншм[ь] си | и шт[ъ]поусти, а пороучникь быс[ть] Девъ, æко вър[ь]ноу емоу | быти. И пакы прїехавшим[ъ] татаром[ъ], и сьтвори лесть, I и предасть ю пакы татаром[ъ], Бакотоу. Потом[ь] же Коуремса [a Genghisid, Horde lineage, + before 1251. - M. V.] I прїиде къ Кремлн[ь]цю и воева около Кремлн[ь]ца. Андръеви ж[е] । на двое бждоущю [Prince Daniel's constable. - M. V.]: овогда възывающюса: «Королевъ | есмъ», - овогда ж[е] татар[ь]скым[ь], дръжащю неправдоу въ | с[ь]рд[ь]ци, Б[ог]ъ предасть и въ ржцъ их[ъ]. Ономоу ж[е] рек[ъ]шю: «Ба| тыева грамота оу мене ес[ть]». Онъм[ъ] же бол[ь]ма възьярив[ъ]|шимсл на н[ь], иа оубїенъ быс[ть], и с[ь]рд[ь]це его вырезаша, и не । оуспъвше ничто оу КремАн[ь]ца, воротишас[А] въ станы своа. I ИзАслав[ъ] [Volodymyrovych. - M. $V$.] же проси оу них[ъ] помощи ити на Галич[ь], они же । рекоша емоу: «Како идеши в Галич[ь], а Данило кнАз[ь] дют[ъ] ес[ть]. | Иже штимет[ь] ти живот[ъ], то кто тА избавит[ь]?». Он[ъ] же 
непо | слоуша их[ъ], но събравь ъ околоу себе, иде в Галич[ь]. Данилш ж[е] I слышавь то, скръбенъ быс[ть], æко в невиденїи се бысть, I посла с[ы]на своего Романа [Danylovych, † between 1258 and

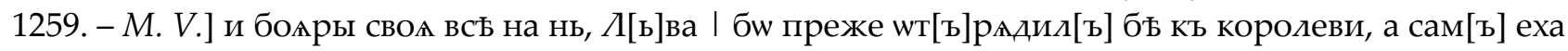

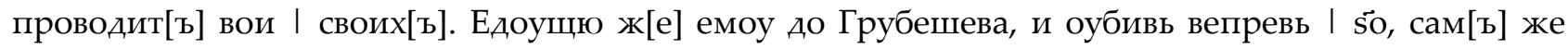
оуби их[ъ] рогатиною $\overrightarrow{\mathrm{r}}$ а три - отроци его, и || въдасть мАса воем[ъ] на пжт[ь], а сам[ъ] пороучивса с[вА]т[о]моу Николь | и реч[е] воем[ъ] своим[ъ]: «Аще сами бждоут[ь] татарове, да не внидет[ь] оужа | сть въ с[ь]рд[ь]ца ваша». Онъм[ъ] же рекшим[ъ]: «Б[ог]ъ бжди помощ[ь]никь ти, । сътворим[ъ] повелен[ь]наа твоа». Поем[ъ] же Роман[ъ] во^, иде ден[ь] и ншщ[ь], І и вънезапоу напад[ъ]шим[ъ] на нА. Ономоу ж[е] не възмог[ъ]шю коуІда оутечи, възбъже на комары ц[ь]рковныа, идеже беІзакон[ь]ные оугре възбъгли бАхж. СтоАщюv ж[е] жколо его кнАІ юю Романоу, жажею вшд[ь]ною измирающи имь, четвертыи I д[ь]нь сниде. КнАз[ь]с же приведе его w[ть]цоу своемоу. Слышав[ъ] же I Девъ, æко Федоръ [emphasis added. - M. V.] посланъ шт[ъ] него къ Солем[ъ], поима сь соІбою слоугы своа, гна по нем[ь], сам[ъ] же оутече, а люди его поима । поехал[ъ] бъ въ оугры" [17, р. 355-361].

The chronicle is based on several narratives, and we are interested in the one telling about the short-lived unsuccessful reign of Prince Iziaslav Volodymyrovych in Halych and in the concluding

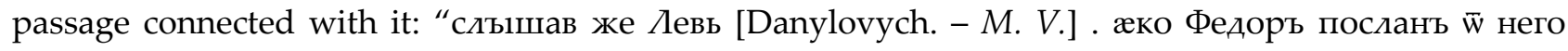
[Iziaslav. - M. V.] ко Солемь [present-day Svaliava in Transcarpathian Region, Ukraine]. и поима со собою слоуги своæ . гна по немъ . самъ же оутече . а людие поима" [17, p. 361].

The most recent analysis of the above lengthy passage was conducted by Vadym Aristov, who argues that it is hardly possible, or imposible, that Prince Iziaslav might have struggled for the Galician throne in 1255 [19, p. 450]. Having made complicated textual reconstructions, the historian believes that this passage "intergrates two texts which [...] refer to different events: the preparations of Iziaslav Volodymyrovych for the campaign against Halych in the 1230s and Kuremsa's attack at Kremenets during his campaign against Volyn" " [19, p. 461]. Thus, according to the historian, the Ruthenian ruler, whose last mention in the narratives of similar sort of events dates as far back as 1236 [19, p. 452], could hardly have been able, after 19 years, to renew attempts to gain possession of Halych. By contrast, he believes that Fedir who is mentioned in the above passage served as an emissionary for the Tatar named Milei, whom the Romanids punished for treason [19, p. 459]. Though the researcher rightly points out that there is "an abundance of toponyms with the root 'cOAb' [meaning "salt", i.e. "sil" in Ukrainian - transl.note] in Galicia" [19, p. 460 note 31], he links the toponym "ко Солемь" with the present-day urban-type settlement called Stara Sil in Staryi Sambir District, Lviv Region (Ukraine).

That being said, however, the researcher leaves the following questions unanswered: Why did Milei send Fedir "ко Солемь" (sic!) and who is Fedir? Nor does the researcher consider the fact that the forces hostile to the Romanids made repeated attempts to reconquer Halych and Galicia taking advantage of the Mongol threat to the Volynian lands owned by Ruthenian princes. In late 1253, Prince Daniel accepted a royal crown from the Pope's legate Opizo in Dorohochyn, thus creating a clear reason for breaking the 1246 agreement with Batu Khan († 1255).

It should be noted that before the publication of V. Aristov's article, the majority of researchers, including Mykola Kotliar, the only author of a special biography of Prince Iziaslav Volodymyrovych [24, p. 228], did not question the fact that Prince Iziaslav had intended to take possession of Halych in 1255 [25, p. 376; 26, p. 154 : Iziaslav Mstyslavovych, not Iziaslav Volodymyrovych; 18, p. 226], though they did not conduct a textual analysis of the above-cited passage as thoroughly as V. Aristov did. The Polish researcher Adrian Jusupović, one of the most recent and most meticulous explorers of the 13thcentury Chronicle of the Romanids, did not find it strange that Prince Iziaslav had made a long (12361254) pause [27, p. 107].

Leaving the textual disputes aside, let us consider more profoundly the content of the above-cited diploma of Junior Queen Elisabeth. It mentions "Lve, cum duobus filiis suis Fudur [emphasis added. M. V.] scilicet et Stephano", who were once rewarded by Rostyslav's wife Anna (datum ante quem 1264) with "[...] terram Borod vocatam in comitatu de Bereg sitam prope Munkaach" [23, p. 98; 28, p. 51]. In our opinion, the localization terram Borod is the equivalent of Barbovo Village (Mukachiv District, 
Transcarpathian Region), which is located at a distance of approximately $25 \mathrm{~km}$ from the Mukachevo mentioned in the act, which may well be described with the word prope. By contrast, the urban-type settlement called Svaliava, which we regard as equivalent to the description "ко Солемь" given in the chronicle, is situated on the famous pathway running from Hungary to Galicia, also at a distance of approximately $25 \mathrm{~km}$ from Mukachevo in a south-westward direction.

A chronological and geographic comparison of the data in the the 13th-century Chronicle of the Romanids, Princess Anna's diploma and Junior Queen Elisabeth's confirmation allows for a cautious identification of the Fedir in the chronicle as the Fedir - the son of a certain Lev. It seems more reasonable to suggest that in 1255 Fedir moved "ко Солемь" because, following the logic of the 1264 confirmation, it might have been very close to his family's realms, including the terra Borod vocata gained by the family during the rule of Rostyslav and his wife in the early 1240s in Comitatibus Abaujvar, Szabolch et Zemplin*. In addition, it is more logical to admit the possibility that it was Prince Iziaslav who might have sent Fedir. Most researchers agree that Prince Iziaslav also belonged to the Olhovids, being a second cousin of Rostyslav Mykhailovych (their common great-grandfather was Prince Sviatoslav Vsevolodovych, +1194). Iziaslav himself used to seek refuge in Hungary, often accompanied by the other boyars from Halych, for instance by Zhyroslav in 1227 [17, p. 117]. He must have had many acquaintances among the nobility there; and after 1245, among the nobility surrounding his second cousin, the king's son-in-law. Thus sending Fedir "ко Солемь" in search of military support seemed like a logical thing to do because it was in the eastern lands of Hungary that Dominus Rostyslav of Machou's family remained in the possession of the property granted by Bela IV. Princess Anna (terminus ante quem 1264) received the Castle of Füzér (present-day Borsod-AbaújZemplén megye, Hungary) from her father [30, No. 70].

It is obvious that Iziaslav Volodymyrovych must have been close with King Bela IV's other son-inlaw, Prince Lev Danylovych, so he was aware of his influence in the court through his wife Constance ( + after 1287/88) and so on. Thus it is no surprise that Lev's detachments might have caught up with Fedir at some place (unspecified in the chronicle) capturing his servants, but not him. Though nothing is known about Fedir's life after the events described in the chronicle, the 1264 donation of Borod and its further confirmation by Junior King Stephan ( +1272$)$ in 1270 seem to refer to this very Fedir, his younger brother Stephan and their father Lev.

"Stephanus dei gratia iunior rex Hungariae, dux Transilvanus [...] volumus pervenire, quod accedens ad nostrum presentiam Leve cum duobus filiis suis, videlicet Fudur et Stephano, literas domine regine iunioris karissime consortis nostre nobis exhibuit humiliter supplicando [...]. Nos igitur peticionem ipsius, quia iusta erat et legitima, regio favore duximus annuendam, ita scilicet, quod et nos ipsam terram predictis Leve et filiis suis, ac eorum heredibus heredumque successoribus, dedimus donavimus et contulimus in perpetuum possidendam, et confirmare ipsas literas domine regine karissime consortis nostre nostrarum presencium literarum munimine roborando" [23, p. 98].

The names Leve/Lve/Lue/Lwe and Fudur/Fudor/Fedor, in contrast to Stephan (Stephanus), are relatively rare in Hungary [31, No. 136, 232; 32, No. 477; 33, p. 126; 34, p. 291; 35, p. 486; 36, p. 162-163; 37, p. 165, 216,$339 ; 38$, p. 88, 159]. Given the assumptions about the relations with Iziaslav Volodymyrovych, it seems logical and understandable that the family obtained land grants right there, in Bereg County, and, just as important, from the wife of Rostyslav Mykhailovych.

Still unresolved is the question about the former homeland of these royal servants. We are inclined to regard them as belonging to the Galician nobility or the newly arrived Chernihiv nobility, who began to sporadically appear in the life of Galicia in the early $13^{\text {th }}$ century $[17$, p. 31-39] and even received land donations from Galician boyars during the time of the Mongol threat. The fact that the diploma granted by Princess Anna or the confirmations issued by the married couple, Junior Queen Elisabeth and Junior King Stephan, do not contain the descriptive word Ruthenus, or a semantically similar word, typically used to refer to those coming from the lands of the Rurikids, does not pose a

\footnotetext{
* $[29, \mathrm{p} 55]$. In one of our previous papers, we expressed the assumption that Lev might have gained this land in reward for fighting at Yaroslav on August 17, 1245 in alliance with Prince Rostyslav Mykhailovych [16, p.120].
} 
problem in this case. Not many newcomers deserved such a description [15, p. 391, 394], nor were the inhabitants of Galicia gene rally referred to as "Ruthenians" in the $12^{\text {th }}$ and $13^{\text {th }}$ centuries. By contrast, within the context of personal communication between the family of Rostyslav Mykhailovych and that of Lev and his sons, the need for such an identification disappeared automatically.

Therefore, in the light of the arguments presented, Lev and his sons, Fedir and Stephan, can be regarded as belonging to the nobility who supported Prince Iziaslav Volodymyrovych and Prince Rostyslav Mykhailovych and who were probably descended from boyars. Lev's son is mentioned in the 1255 chronicle as well as among the lords of Borod Land in Bereg County [23, p. 98; 28, p. 51]. One of the best explorers of the historical geography of the Hungarian Kingdom, György Györffy, believed that it was not known from the charters of the $13^{\text {th }}$ and $14^{\text {th }}$ centuries who the other recipients of the land grant were [39, p. 535-536]; however, we know exactly that Fedir had a family. On August 28, 1313, after a thorough examination, Charles Robert confirmed the donation of Borod to Fedir's son Leuenthke [40, p. 28; 41, p. 266]. Fedir's other children, Thoma dictus Fodor and his daughter Elisabeth (with Georgius, her husband, and comes Blasius, their adult son), are mentioned in the 1356 cadastre of Borod [42, p. 75, 224, 226, 246-248, 317]. The time of Fedir's first mention in the charters suggests that 1239/40 should represent a terminus ante quem for his birth, which is another reason to believe that he was the one mentioned in the 1255 chronicle. Lev's other son might also have belonged to the court of Iziaslav Volodymyrovych. For their merits, no record of which is available, he, his brother and father were granted Borod Land in Bereg County near Mukachevo by the wife of Rostyslav Mykhailovych [23, p. 125].

\section{CONCLUSIONS}

Therefore, we consider it possible to conclude that Lev and his sons, Fedir and Stephan, were among those who followed Prince Rostyslav Mykhailovych to Hungarian lands after 1245 or during the next fifteen years. The above-mentioned individuals must have been descended from the boyars of Chernihiv or Halych. Considering Lev's age, he might have participated in the battle at Yaroslav on August 17, 1245 and might have been rewarded by Prince Rostyslav in the Hungarian kingdom, his new homeland. By contrast, his son Fedir must have been supporting Iziaslav, the son of Prince Volodymyr Ihorovych executed by Galician boyars in 1210/11, in his (albeit unsuccessful) attempt to gain possession of Halych while taking advantage of the Mongol threat to the lands of the Romanids in 1255. The latter event was recorded the 13th-century Chronicle of the Romanids. Though some researchers may rightly question the credibility of the textual criticism of the chronicle, its comparison with the 1264-1270 Hungarian charters allows for the possibility of identifying this particular Fedir as the lord of Borod Land located near Mukachevo in Bereg County.

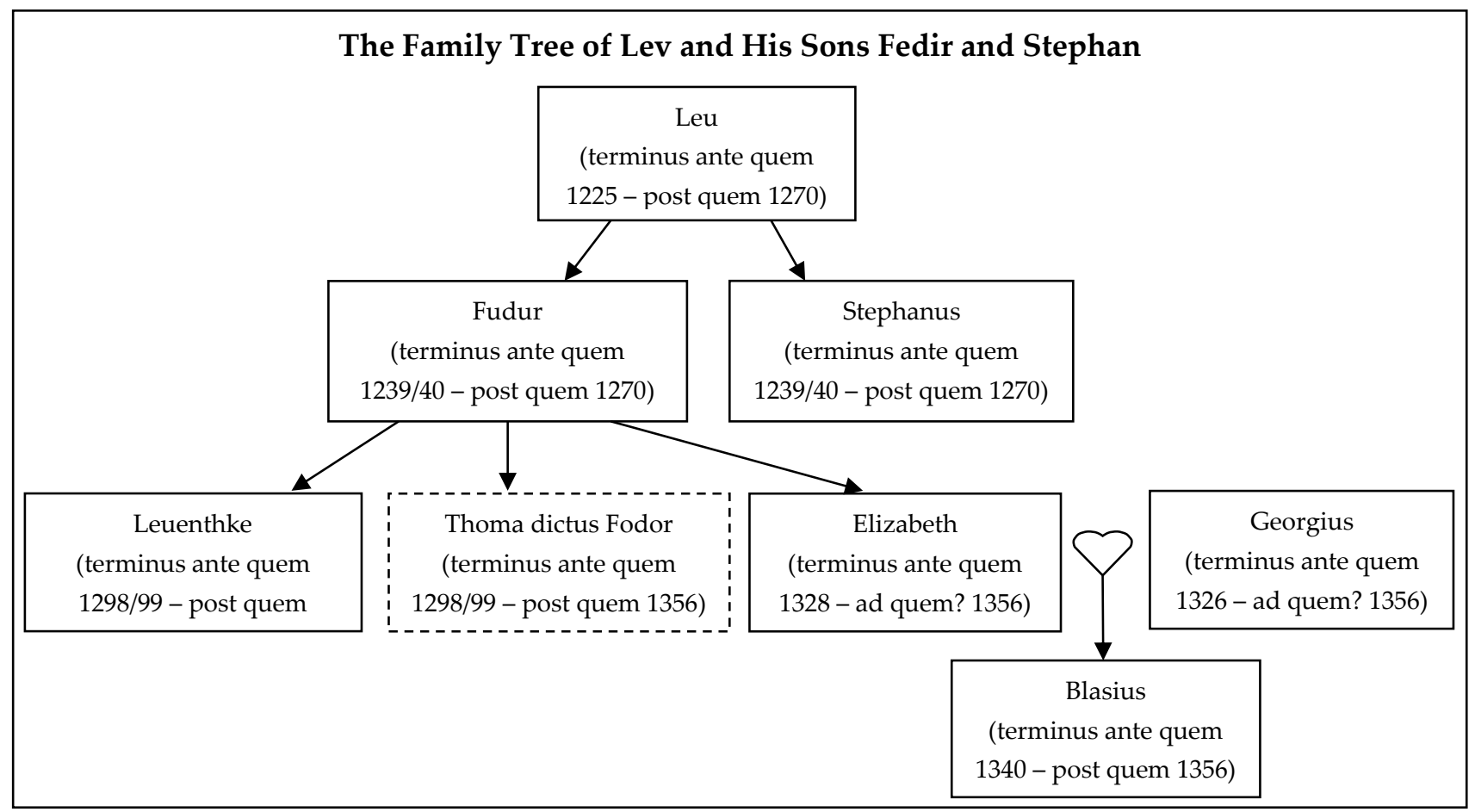




\section{REFERENCES}

[1] Харди Ђ. Итинерариј Ростислава Михаиловича. Историјски архив СРЕМ, Сремска Митровица; Нови Сад; Сремска Митровица, 2019.

[Hardi Đ. Itinerariy Rostislava Mikhailovicha. Istoriyski arkhiv SREM, Sremska Mitrovitsa; Novi Sad; Sremska Mitrovitsa, 2019.]

[2] Dąbrowski D. Książę w drodze. O mobilności Rurykowiczów w XIII w. na przykładzie Daniela Romanowicza. Klasyfikacja podróży. Slavia Orientalis, LXIV (2015) 1, 7-34.

[3] Dąbrowski D. Książę w drodze. O mobilności Rurykowiczów w XIII w. na przykładzie Daniela Romanowicza. Klasyfikacja podróży. Slavia Orientalis, LXIV (2015) 2, 207-227.

[4] Тодорова С. Дъщерята на Ростислав Михайлович и събитията в Бъдгария от средата на XIII в. Исторически преглед, 2 (1989), 52-57.

[Todorova S. Dshcheryata Rostislav Mikhaylovich i sbitiyata v Blgariya ot sredata na XIII v. Istoricheski prehled, 2 (1989), 52-57.]

[5] Jan L. In ordine Cruciferorum Christo militavit. K osudům Ješka, syna Záviše z Falkenštejna a královny Kunhuty. Český časopis historický, 98 (3) (2000), 453-475.

[6] Бубало Ђ. Бела Ростислављевић. В: Српски биографски речник, Т. 1 : А-Б. Нови Сад, 2004, 465-466. [Bubalo D. Bela Rostislavlyevich. In: Srpski biografski rechnik, T. 1 : A-B. Novi Sad, 2004, 465-466.]

[7] Šretr O. Kunhuta uherská. královna česká ( ${ }^{*}$ asi 1245-46 +9.9.1285). Bakalářská diplomová práce. Brno, 2008.

[8] Харди Ђ. Михаило Ростиславич. В: Сриски биографски речник, Т. 6: Мар-Миш. Нови Сад, 2014, 844. [Hardi Đ. Mikhailo Rostislavich. In: Srpski biografski rechnik, T. 6: Mar-Mysh. Novi Sad, 2014, 844.]

[9] Волощук М. Княгиня Грифіна Ростиславівна, ії польський шлюб та ймовірне руське оточення двору. ГАЯИЧИНА: науковий і культурно-просвітній краєзнавчий часопис, 28 (2016), 12-19.

[Voloshchuk M. Kniagynia Gryfina Rostyslavivna, yii polskyi shliub ta ymovirne rus'ke otochennia dvoru. Halychyna, 28 (2016), 12-19.]

[10] Волощук М. Єпископ Кракова Procopius de Russia (1292/93-1295рр.). Умовна етнічність та генеалогічна належність. In: Dąbrowski Dariusz, Jusupović Adrian, Maresz T. (Ed.) Monografie Pracowni Badań nad Dziejami Rusi Uniwersytetu Kazimierza Wielkiego, T. 5: Polska, Ruś i Węgry: X-XIV w. Avalon, Kraków, 2018, 99-129.

[Voloshchuk M. Yepyskop Krakova Procopius de Russia (1292/93-1295 rr.). Umovna etnichnist' ta genealogichna nalezhnist’. In: Dąbrowski Dariusz, Jusupović Adrian, Maresz T. (Ed.) Monografie Pracowni Badań nad Dziejami Rusi Uniwersytetu Kazimierza Wielkiego, T.5: Polska, Ruś i Węgry: X-XIV w. Avalon, Kraków, 2018, 99-129.]

[11] Dimnik M. The Dynasty of Chernigov 1146-1246. Cambridge University Press, Cambridge; New-York, 2003.

[12] Харди Ћ. Руски монаси, духовници и преписивачи на тлу Срема у средњем веку. Споменища историјског архива "Срем". Сремска Митровица, 4 (2005), 79-90.

[Hardi Đ. Ruski monasi i prepisivachi na tlu Srema u sryednyem veku. Spamevnitsa istoriyskog arkhiva "Srem". Sremska Mitrovitsa, 4 (2005), 79-90.]

[13] Носенко А. Константин "Рязанский и Евстафий Константинович: к вопросу о княжеском происхождении и родственных связях. Colloquia Russica I (5) (2015), 161-172.

[Nosenko A. Konstantin "Ryazanskiy" i Evstafiy Konstantinovich: k voprosu o knyazheskom proiskhozhdenii i rodstvennykh svyazyach. Colloquia Russica I (5) (2015), 161-172.]

[14] Мартынюк А. До Герберитейна: Австрия и Восточная Европа в системе персональных связей и культурных контактов (XIII - начало XVI века). Квадрига, Москва, 2019.

[Martyniuk A. Do Gerbersteina: Avstriya i Vostochnaya Evropa $v$ sisteme personal'nykh svyazey i kulturnykh kontaktov (XIII - nachalo XVI veka), Kvadriga, Moskva, 2019.]

[15] Волощук М. "Русь" в Угорському королівстві (XI - друга половина XIV ст.): суспільно-політична роль, майнові стосунки, міграції. Лілея-НВ, Івано-Франківськ, 2014.

[Voloshchuk M. "Rusz" v Uhors'komu korolivstvi (XI - druga polovyna XIV st.): suspilno-politychna rol', maynovi stosunky, migracii. Lileia-NV, Ivano-Frankivsk, 2014.]

[16] Волощук М. Просопографічні студії битви під Ярославом 17 серпня 1245 року. Colloquia Russica, II (3) (2017), 112-121. 
[Voloshchuk M. Prosopografichni studii bytvy pis Yaroslavom 17 serpnia 1245 roku. Colloquia Russica, II (3) (2017), 112-121.]

[17] Dąbrowski D, Jusupocić H. (Ed.). Chronica Galiciano-Voliniana. Monumenta Poloniae historica. Nova series PAU; PWN, Kraków; Warszawa, 2017.

[18] Homza Martin, Malinovská Nora (Ed.). Haličsko-volynská kronika. Neznáme rozprávanie o rodine králov a kniežat východo-strednej Európy v 13. storočí. Matica Slovenská, Martin, 2019.

[19] Арістов В. Як не ходив на Галич князь Ізяслав у 1250-х роках. В: Боряк Г. (ред.) Academia. Terra Historiae. Студї на пошану Валерія Смолія, 2. Ін-т історії України національної Академії наук України, ДУ Інститут всесвітньої історії Національної Академії наук України, Київ, 2020, 447-462. [Aristov V. Yak ne khodyv na Galych kniaz' Izyaslav u 1250-kh rokakh. In: Boryak G. (Ed.) Academia. Terra Historiae. Studii na poshanu Valeriya Smoliya, 2. In-t istorii Ukrainy natsionalnoyi Akademii nauk Ukrainy, DU Instytut vsesvitnyoi istorii Natsionalnoi Akademii nauk Ukrainy, Kyiv, 2020, 447-462.]

[20] Kristó Gy. sztb. (Ed.) Anjou-kori oklevéltár. Budapest; Szeged, 1990, 1-38.

[21] Voloshchuk M. Ruthenian-Hungarian matrimonial connections in the context of the Rurik dynasty inter-dynasty policy of the 10th-14th centuries: selected statistical data. Codrul Cosminului, XXIV (3) (2018), 7-30.

[22] Грушевський М. Історія України-Руси, 2. Наук. думка, Київ, 1993. [Grushevskyy M. Istoriya Ukrainy-Rusy, 2. Nauk. dumka, Kyiv, 1993.]

[23] Nagy E. (Ed.) Codex diplomaticus patrius, 8. Franklin-Társulat Könyvnyomdája, Budapestini, 1880.

[24] Котляр М. Загадковий ворог Романовичів В. Котляр М. Історія України в особах. Давньоруська держава. Україна, Київ, 1996.

[Kotliar M. Zagadkovyy vorog Romanovychiv. In: Kotliar M. Istoriya Ukrainy v osobakh. Davnyoruska derzhava. Ukraina, Kyiv, 1996.]

[25] Dąbrowski D. Daniel Romanowicz król Rusi (ok. 1201-1264). Biografia polityczna, 1. Avalon, Kraków, 2012.

[26] Александрович В., Войтович А. Король Данила Романович (Славетні постаті Середньовіччя. Вип. 3). Вид. Пшонківський О. В., Біла Церква, 2013.

[Aleksandrovych V., Voytovych L. Korol Danylo Romanovych (Slavetni postati serednyovicchia, Vyp. 3). Vyd. Pshonkivskyi O. V., Bila Tserkva, 2013.]

[27] Jusupović A. Kronika halicko-wołyńska (Kronika Romanowiczów) w latopisarskiej kolekcji historycznej. Avalon, Kraków; Warszawa, 2019.

[28] Szentpétery I. (Ed.) Regesta rerum stirpis Arpadianae critico-diplomatica, 2: (1255) 1270-1301), 1: (12551272). Kiadja a Magyar Tudományos Akademia, Budapest, 1943.

[29] Fejer G. (Ed.) Codex diplomaticus Hungariae ecclesiasticus ac civilis, 5/1. Typis Typogr. Regiae Universitatis Ungaricae, Budae, 1829.

[30] Wenzel G. (Ed.) Codex diplomaticus Arpadianus continuatus, 3 (1261-1272). Magyar Tudományos Akadémia, Pest, 1862.

[31] Wenzel G. (Ed.) Codex diplomaticus Arpadianus continuatus, 7 (1235-1260). Magyar Tudományos Akadémia, Pest, 1869.

[32] Wenzel G. (Ed.) Codex diplomaticus Arpadianus continuatus, 12 (1274-1300). Magyar Tudományos Akadémia, Pest, 1874.

[33] Fejer G. (Ed.) Codex diplomaticus Hungariae ecclesiasticus ac civilis, 6/1. Typis Typogr. Regiae Universitatis Ungaricae, Budae, 1830.

[34] Fejer G. (Ed.) Codex diplomaticus Hungariae ecclesiasticus ac civilis, 8/2. Typis Typogr. Regiae Universitatis Ungaricae, Budae, 1832.

[35] Fejer G. (Ed.) Codex diplomaticus Hungariae ecclesiasticus ac civilis, 8/3. Typis Typogr. Regiae Universitatis Ungaricae, Budae, 1832.

[36] Nagy E., Stummer A., Ráth C., Véghely D. (Ed.) Codex diplomaticus patrius. Hazai okmánytár, 4. Typis Victoris Sauervein, Györött, 1867.

[37] Ipolyi A., Nagy E., Véghely D. (Ed.) Codex diplomaticus patrius. Hazai okmánytár, 6. Typis Alexsandri Kocsi, Budapestini, 1876.

[38] Ipolyi A., Nagy E., Véghely D. (Ed.) Codex diplomaticus patrius. Hazai okmánytár, 7. Typis Alexsandri Kocsi, Budapestini, 1880.

[39] Györffy Gy. Az Árpadkori Magyarország történeti földrajza, 1 (A-Cs). Akademiae kiadó, Budapest, 1966. 
[40] Neumann Tibor. Bereg megye hatóságának oklevelei (1299-1526). Móricz Zsigmond Könyvtár, Nyíregyháza, 2006.

[41] Kristó Gy. (Ed.). Anjou-kori oklevéltár, 3 (1311-1314). Kulturális hagyamányaink feltárása nyilványtartása és kiadása, Budapest ; Szeged, 1994.

[42] Rábai K. (Ed.). Anjou-kori oklevéltár, 40 (1356). Quintus Kiadó, Budapest ; Szeged, 2014.

Address: Myroslav Voloshchuk, Vasyl Stefanyk Precarpathian National University, 57 Shevchenko St., Ivano-Frankivsk, 76025 Ukraine.

E-mail: myrkomyrko79@gmail.com

Received: May 19, 2020; revised: November 16, 2020.

Волощук Мирослав. Оточення князя і господаря Мачви Ростислава Михайловича в Угорщині (з історії однієї родини другої половини XIII - середини XIV ст.). Журнал Прикарпатського університету імені Василя Стефаника, 7 (2) (2020), 42-50.

Однією із найменш досліджених сторінок біографії руського князя, племінника «за кужелем» короля Русі Данила Романовича - Ростислава Михайловича є його оточення в межах нової батьківщини - Угорського королівства поміж 1242/43-1262/64 pр. Із різнопланових джерел відомо про велику кількість його прихильників серед світської та церковної знаті не тільки в Угорщині, а й у Галицькій, Чернігівській та Болоховській землях. Однак про чітко названих джерелами осіб, що розділили долю князя-втікача в землях короля Бели IV особливо після поразки під Ярославом 17 серпня 1245 р., досі було відомо мало. Ми, шляхом верифікації дітописних звісток та угорського актового матеріалу, дійшли висновку, що до близьких родині Ростислава Михайловича і принцеси Анни осіб сміливо можна залічити Лева, його синів Федора й Стефана - держателів землі Borod поблизу Мукачевого у комітаті Берег. Ці, вочевидь знатні з походження люди, могди належати до чернігівської або галицької знаті, почергово, але безуспішно, підтримуючи упродовж 40-50-х рр. XIII ст. самого князя Ростислава або ж його троюрідного брата Ізяслава Володимировича на галицький престол. Що важливо, завжди такі інспірації співпадали із монгольською загрозою вторгнення у володіння Романовичів, що додавало у перспективі претендентам на Гадич додаткових шансів на успіх, утім - завжди невдало. За свої заслуги перед зятем угорського короля донька останнього Анна terminus ante quem 1264 р. ушанувала їх відповідним земельним наданням, котре почергово конфірмували як останні представники династії Арпадів на угорському престолі, так і нові королі з династії Анжу. Володіння Borod перебувало у власності родини щонайменше до другої подовини XIV ст.

Ключові слова: Ростислав Михайлович, принцеса Анна, Ізяслав Володимирович, Галич, Галицька земля, знатні Дев та його сини Федір і Стефан, комітат Берег, Мукачево, земля Borod, Свалява, хроніка Романовичів XIII ст., угорський актовий матеріал. 